\title{
Strip Malls, City Trees, and Community Values
}

\author{
Kathleen L. Wolf
}

\begin{abstract}
Strip malls (also known as mini-malls) are a common urban land use, historically promoted by U.S. zoning practices that concentrate retail and commercial development in a narrow band along arterials and major streets. More recently, communities are redeveloping mini-mall zones, expanding landscape plantings as biotechnology, and attempting to create a sense of place. This study assessed public response to urban forest and landscape options. Surveys depicted varied roadside, property-edge treatments. Residents of three major cities in the Pacific Northwest, U.S., were asked to indicate their preferences and perceptions concerning a four-concept framework: visual quality, retail perceptions, patronage behavior, and pricing for goods and services. Respondents preferred landscaped roadsides and report positive retail behavior such as willingness-to-pay $8.8 \%$ more for goods and services in well-landscaped malls. Roadside management guidelines are proposed based on the research results.
\end{abstract}

Key Words. Contingent valuation; mall; preference; public response; retail; roadside; survey; visual quality.

Strip malls have become a prevalent commercial land use throughout the United States. They offer small-scale retail and commercial services and products, generally serving local communities. These commercial hubs are often deplored for their inefficient use of space and lack of visual quality, yet they are often the product of local zoning practices that encourage concentration of small businesses in off-street centers.

Many communities are interested in either improving the visual quality of new commercial corridors or redeveloping existing commercial streets to better align with community values concerning sustainability. Survey research was done to learn more about public perceptions of urban strip malls and to suggest landscape practices for communities or developers who want to improve the visual quality of a strip mall setting. Prior studies show positive shopper inferences about businesses in central business districts having a quality landscape (Wolf 2005). Similar principles and methods were used to explore public response to strip mall landscape alternatives.

\section{BACKGROUND}

\section{Mini-Malls}

The first strip mall shopping center in the United States was the Country Club Plaza in Kansas City, Missouri, built in the 1920s (Strip Mall 2007). Strip malls (also known as mini-malls) are now ubiquitous in urbanized areas, consisting of a row of multiple (usually connected) storefronts having associated off-street parking. Although fairly new in human history, the strip mall reflects ancient commercial planning; a road focuses the movement of people and some of those passersby will want to buy something. Because many U.S. cities conduct single-use zoning, retail and commercial zones are often concentrated in a narrow band along arterials and highways with residential communities located nearby.

Mini-malls are service-oriented and usually contain smallscale stores that serve everyday needs of nearby residents (such as a video store or a small restaurant). They serve dual purposes of shopping convenience for nearby residential communities and provide relatively inexpensive retail spaces for startup and small businesses. Therein lies the tension. Built at fairly low cost, and visible to thousands who drive by each day, strip malls are criticized for being ugly, contributing to the demise of traditional business districts, and reducing social interactions among shoppers. Nonetheless, strip mall architecture is simple and sturdy, maximizing usable space while keeping real estate costs low. Businesses having slim profit margins and low capital reserves are able to rent or lease affordable retail space and offer basic goods and services to a community (Stewart 2005).

\section{Urban Landscape Assessment}

Landscape assessment studies have been used since the 1960s to explore public perceptions and values associated with landscapes and their management. Generally, people of all ages and cultural backgrounds prefer natural views to built settings, and unkept nature in urban settings is less preferred than well-maintained nature. The presence of trees generally enhances public judgment of visual quality in cities (Ulrich 1986; Smardon 1988; Dwyer et al. 1994). Urban scenes containing trees (particularly large ones) are consistently highly preferred (Ulrich 1986), and the general public rates the benefits of urban trees highly (Lohr et al. 2004).

Plants contribute to roadside visual quality. In a California study (Evans and Wood 1980), people judged simulations of proposed residential development for scenic quality and preferred highly vegetated highway corridors. Van passengers recorded attractiveness ratings for urban roadside views in Minnesota (Nassauer and Larson 2004); highest values were awarded to road segments having nature features and well-designed plantings and structural elements. A national study found that drivers prefer urban expressway landscapes having large trees that screen adjacent commercial properties (Wolf 2003, 2006).

\section{Community Economics}

Psychologic assessments of urban landscapes suggest that aesthetic response is more than a mere reaction to what is beautiful or pleasant, but is an expression of a complex array of perceptual and cognitive processes (Kaplan and Kaplan 1989). Public responses have economic consequences. Talented workers and 
firms are attracted to places that have high levels of amenities and environmental quality (Florida 2005). Real estate values are enhanced by landscape and vegetation. Market prices of homes are increased approximately $7 \%$ by the presence of trees in yards and at the property edge, and those homes near a naturalistic open space gain 10 to $20 \%$ in value (Wolf 2007).

Trees and nature also generate economic benefits for commercial and retail enterprises. In one study, rental rates were $7 \%$ higher for commercial office properties having a quality landscape (Laverne and Winson-Geideman 2003). In studies of downtown business districts, shoppers report increased patronage and purchasing behavior in districts having a quality urban forest. Consumers report being willing to pay $9 \%$ to $12 \%$ more for goods and services in districts having a mature tree canopy (Wolf 2005). Merchants pay close attention to the quality of indoor design features such as product layout, music, and store lighting. Shoppers accept higher prices for goods in stores having attractive settings and positive staff. Visual quality of the outdoor environment appears to also impact price behavior (Wolf 2004).

\section{METHODS AND PROCEDURES}

\section{Research Questions}

Some communities have concerns about the aesthetics of retail areas and are also working to improve the ecosystem services within built landscapes. Several research questions guided a social science study to learn more about public response to the presence of plants in strip mall environments:

1) How does vegetation influence public response to visual quality of strip mall developments?
2) Are there any differences in consumers' patronage behavior related to a mall's visual amenities?

3) Does landscape character influence what consumers would be willing to pay for goods and services?

\section{Survey Construction}

Survey methods were selected to conduct the research. An eightpage photo questionnaire began with a photo preference exercise. A photographic image sample was generated using a combination of photography of actual strip mall settings and digital editing. Three base images depicted building and parking conditions typical of strip malls in temperate North American cities. Image selection was done to reduce variability of visual content and known confounds in public preference response were avoided such as overhead utility lines, tidiness, and upkeep (Nasar 1987; Herzog and Gale 1996). Each base image was digitally edited to represent eight conditions of varied landscape treatment of vegetation structure (tree and shrub combinations), management approach (whether manicured or naturalistic), and spacing (linear equidistant or random). The final presentation set contained 27 black and white images; 26 were randomly presented in the questionnaire. Respondents rated how much they liked each image on a Likert scale from $1=$ not at all to $5=$ very much and high preference.

Several additional banks of variables were provided to test consumer perceptions and behavior associated with varied landscape scenarios. Two hypothetical scenarios were constructed using photographic composites and plan sketches (Figure 1). Scenarios differed with respect to quantity and arrangement of vegetation. Secondary visual distractions (such as litter, building age, and

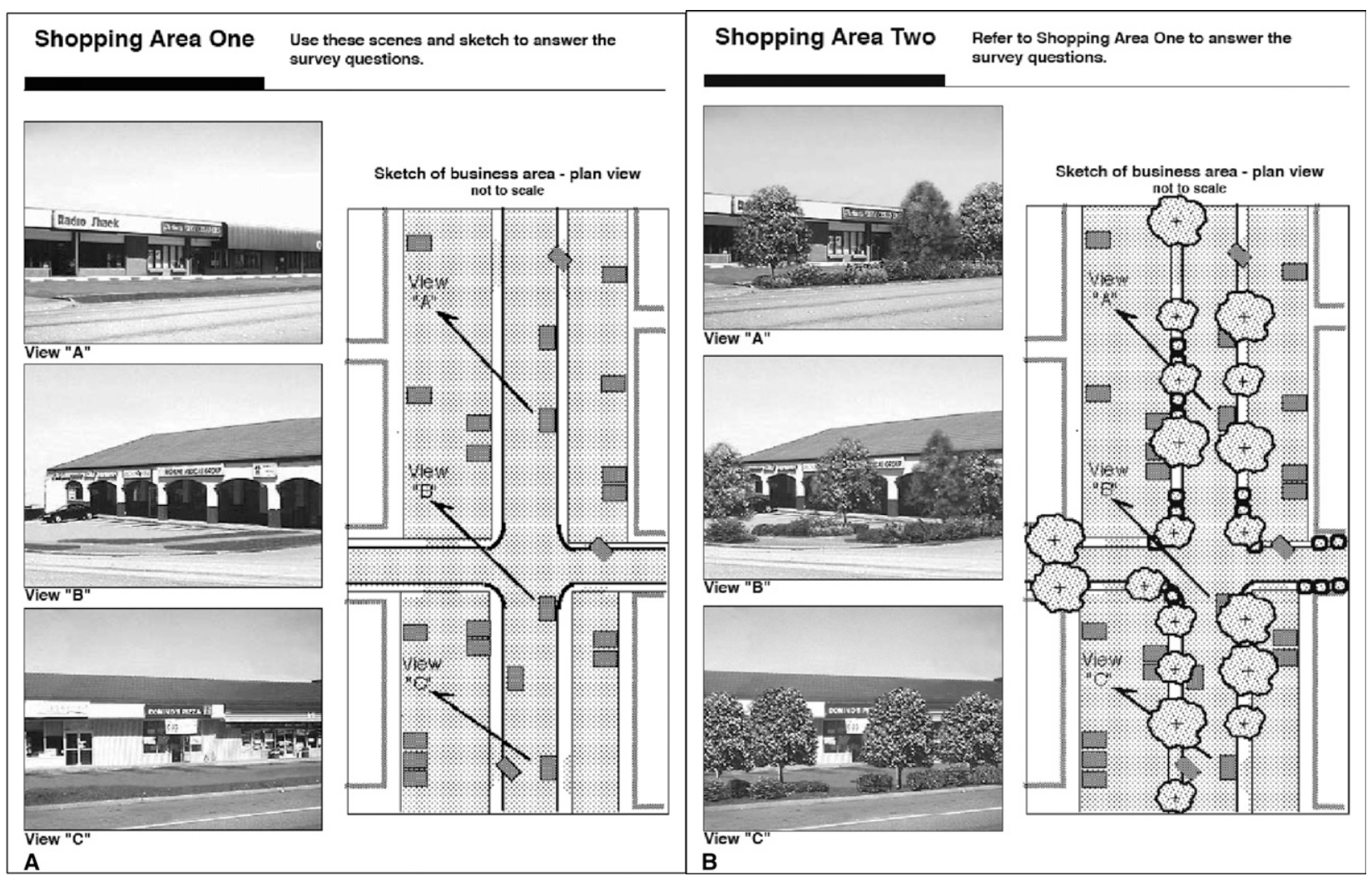

Figure 1. Visual presentation of survey scenarios. 
utility lines) were avoided. The No Vegetation district scenes contain no trees or shrubs, showing uninterrupted rows of storefronts. The Mature Vegetation scenario depicts a similar street scene with street trees of mature height and associated shrubs. No conflicts of trees with structures or infrastructure are apparent.

Respondents were asked to project their shopping behavior. Each respondent saw both scenarios but responded to one hypothetical place. Three sets of variables measured consumer response. Respondents provided ratings on perceptual descriptions of the district and reported their likely behavior on five patronage variables. A final section presented a contingent valuation method exercise, asking respondents to indicate their willingness-to-pay values for a list of goods and services. Contingent valuation is an economic analysis tool typically used to assess values for nonmarket, environmental public goods (such as wildlife conservation, clean air, and environmental protection). In this study, the tool was applied to an urban forest environment.

\section{Respondent Sampling}

Residents of three major cities in the Pacific Northwest region of the United States were selected for the survey sample frame: Seattle, Washington; Tacoma, Washington; and Portland, Oregon. These cities were chosen because they are the three largest population centers in the geographic region and have extensive strip mall development. It was assumed that the selected respondent populations and the strip mall settings of these cities do not differ distinctly from other temperate climate urban centers.

A random list of mailing addresses was purchased from a commercial list broker generated within zip codes selected to represent typical urban areas having strip malls. After pretesting, self-administered surveys were mailed to a sample of 1,200 households. Mailing procedures (including reminders) generated 165 reasonably complete responses, and given that 63 were nondeliverable or not completed, the response rate was $14.5 \%$. A $20 \%$ to $25 \%$ return was expected of urban mail surveys decades ago (Sommer et al. 1990), but response rates have fallen (Elmendorf and Luloff 2001).

The questionnaire ended with several demographic and background items. Thirty-three percent of respondents were in their 20 s and 30 s, $44 \%$ were in their 40 s and 50 s, and $24 \%$ were in their 60 s or older. The majority of respondents were male $(60 \%)$ and white $(85 \%)$. Twelve percent of responding households contained a single person, whereas $36 \%$ were two-person households with $46 \%$ claiming to be composed of three or more persons. Fortyseven percent of households had persons 18 years or younger. Stated annual household income varied considerably. Twentyone percent claimed $\$ 35,000$ or less per year, $49 \%$ selected the $\$ 35,000$ to 50,000 range, whereas $30 \%$ earn greater than $\$ 75,000$ annually. Meanwhile, U.S. median household earnings for the study year were $\$ 38,885$ and regionally $\$ 39,067$ for Oregon and $\$ 47,421$ for Washington states.

There are issues of generalizability resulting from survey response. The low response rate raises possibilities of nonresponse and/or self-selection bias. Resources were not available to test for nonresponse issues. Also, the respondent profile indicates potential inference limitations with regard to gender and ethnicity.

\section{ANALYSIS AND RESULTS}

Data analysis involved several approaches. Descriptive statistics, followed by factor analysis, revealed categories of response in the preference ratings. For scenarios, individual response items were first tallied, then combined using data reduction methods to look for underlying categories, and then compared for differences in response between conditions of streets having and not having trees.

\section{Visual Preference}

Prompt images depicted a gradient of vegetation treatments. Does the presence of vegetation affect visual quality of small mall retail settings? Considering the range of mean preference ratings, scenes having only lawn in the foreground came in at approximately 1.5 and display uninterrupted views of mall buildings. Images having trees, alone or in association with shrubs, registered the highest means of approximately 3 to 3.5 .

Principal axis factor analysis with Varimax rotation was used to extract underlying common dimensions based on observed covariation of individual images. Several decision rules were used to determine inclusion of any item within a specific category (Kaplan and Kaplan 1989). Four categories emerged from the analytic procedure, accounting for $66 \%$ of the total variable variance, and included 25 images.

Each group was assigned an assemblage epithet describing principal content. After dimensional analysis, new variables were constructed by aggregating means across all category items (Figure 2).

Factor analysis categories typically reflect multiple perceptual influences such as vegetation content, spatial configuration, and built to nature balance. The images of Mixed Screen display a combination of trees and shrubs at the property edge. The vegetation composition is varied, depicting mixed species and irregular placement of plants. Foreground landscape obscures views of midground buildings. Ordered Trees images contain large trees planted in regular order at the property edge with the ground plane planted in grass. Category 3, Shrub Edge, depicts border plantings of both sheared and naturalistically maintained lowgrowing shrubs. Unlike the two other categories, background buildings are in full view behind the vegetated edge. The base images, containing No Vegetation in the foreground, formed a fourth category with uninterrupted views of a parking area and buildings.

The lowest rated category contains views of strip mall buildings visually unmitigated by landscape vegetation. From the most barren scenes of buildings and parking lots, category preference means increase with increased quantities and structure of vegetation. Preference ratings take a major step up with the addition of shrub and hedge plant materials. Another preference increment is added when trees are planted with the highest visual quality values being assigned to tree plantings having associated shrub materials.

\section{Scenario Analysis}

\section{Place Perceptions}

While viewing two scenarios, respondents were asked to rate their level of agreement with a series of descriptive statements about one of the locations using Likert scales ( 1 = "strongly disagree" to 7 = "strongly agree"). Categories were statistically derived and labeled using the analytic approaches described for visual preference data. Four categories contained 16 of 25 original items 


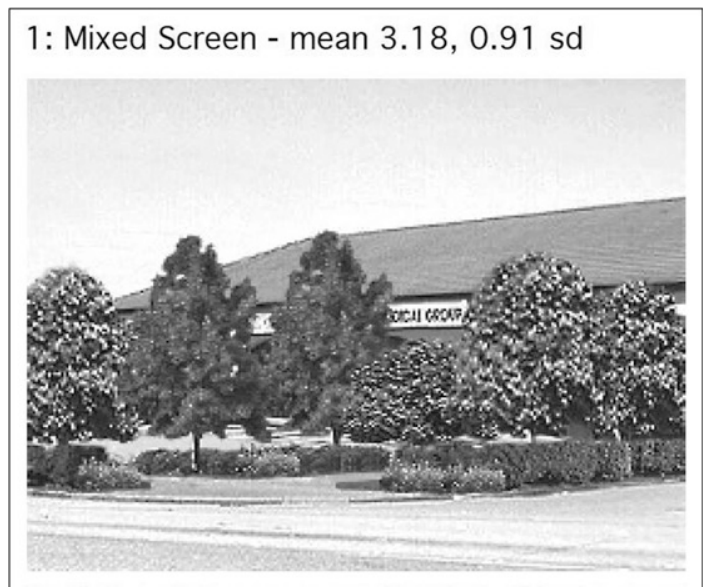

2: Ordered Trees, mean 3.09, $0.78 \mathrm{sd}$

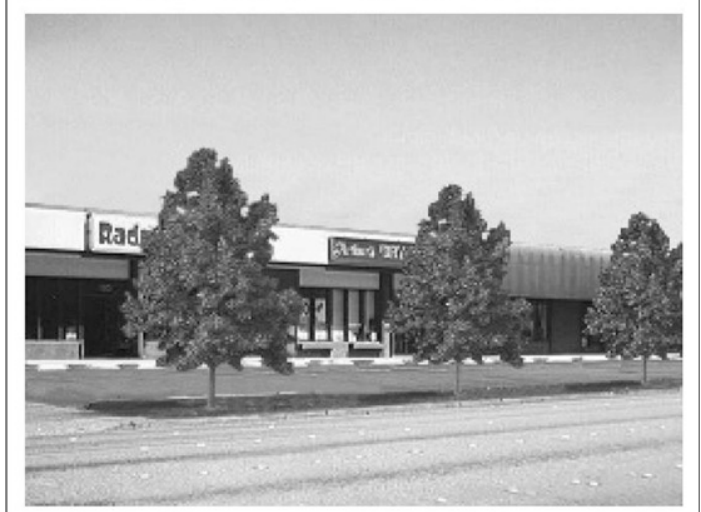

3: Shrub Edge, mean 2.35, $0.96 \mathrm{sd}$

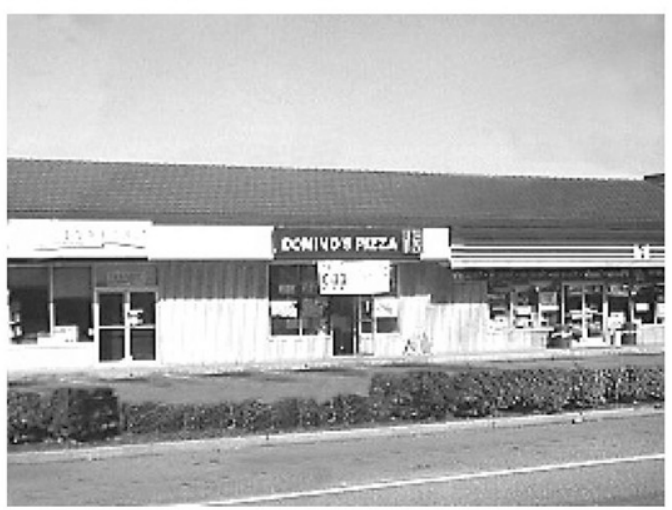

4: No Vegetation, mean $1.39,0.83 \mathrm{sd}$

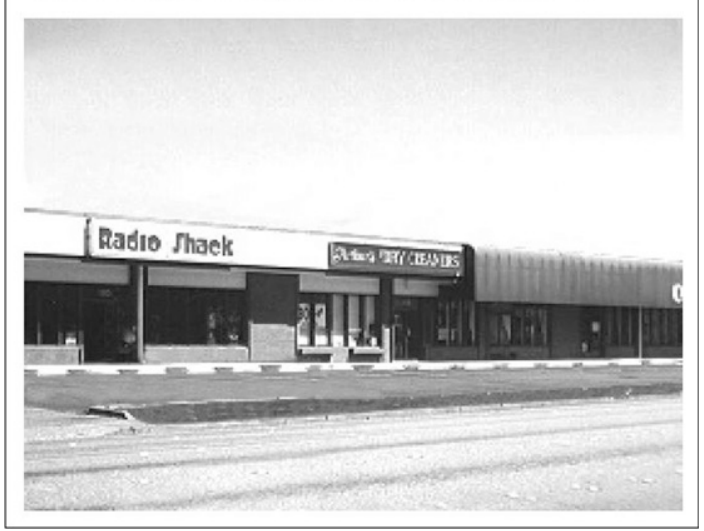

Figure 2. Image preference categories.
Table 1. Place perceptions-categories and means comparisons.

\begin{tabular}{llll}
\hline & \multicolumn{3}{c}{ Scenario } \\
\cline { 2 - 4 } & $\begin{array}{l}\text { No } \\
\text { Vegetation }\end{array}$ & $\begin{array}{l}\text { Mature } \\
\text { Vegetation }\end{array}$ & $\begin{array}{l}\text { Independent samples } \\
\text { [Mean (SD)] }\end{array}$ \\
$\mathrm{t}$-test
\end{tabular}

Note. Item ratings: 1 = strongly disagree through $7=$ strongly agree.

and accounted for $60 \%$ of total variance. Individual variables were combined to construct dummy variables, and responses were compared between the mall scenarios (Table 1) using alpha levels that were adjusted for multiple comparisons $(0.05 / 4=$ $0.0125)$.

The presence of trees and shrubs enhances judgments of Amenities and Attractions. Respondents strongly inferred that the green mall was associated with a more positive atmosphere, cleanliness, image and to be a more favorable place for residents and tourists alike. Such findings are not surprising because prior studies about nature and city streets found that evaluative appraisals (Nasar 1987) and affective response (Sheets and Manzer 1991) are boosted by the presence of trees.

Results for categories Business Quality and Positive Merchants are informative. There was no obvious indication of the condition of neither stores nor merchants, yet respondents attributed significantly better business conditions and interactions for the scenario with more plantings. Quality and selection of products, level of customer service, and merchant helpfulness were all judged to be more positive in the vegetated mall. This finding is consistent with positive judgments of merchants and shops found in studies of central business districts that have a quality urban forest canopy (Wolf 2005). A consumer's cognitive interpretations and representations of place extend to include the quality of social interaction and response that he or she expects.

An inverse relationship was found for the Wayfinding category. Study participants highlighted the common complaint of business people that vegetation can restrict visibility of signage and storefronts. Drive-by views and the search for a particular store may be hindered by dense lot-edge landscape.

\section{Shopper Patronage}

Respondents were queried about potential patronage behavior using categorical response variables (Table 2). Response frequencies were analyzed to evaluate the relationship of reported actions to mall character. Responses on all but one patronage variable were found to be significantly higher when comparing Mature Vegetation to No Vegetation conditions.

An inverse pattern of response was evident. Responses for novegetation settings are concentrated at the low end of each of the patronage variables' values and become less frequent moving toward the high end. Mature Vegetation malls exhibit fewer low value responses, and response frequencies increase across higher values. Associations of positive patronage response to landscaped 
Table 2. Patronage variables-scenario comparisons.

\begin{tabular}{lll}
\hline & \multicolumn{2}{c}{ Scenarios } \\
\cline { 2 - 3 } Patronage variable & $\begin{array}{l}\text { No } \\
\text { Vegetation }\end{array}$ & $\begin{array}{l}\text { Mature } \\
\text { Vegetation }\end{array}$ \\
\hline Time willing to travel to reach place? & & \\
Pearson $\chi^{2}=11.310, P<0.004$, Cramer's & & \\
$\quad$ V $=0.271$ & & \\
Less than 10 min & 55 & 32 \\
10 to 20 min & 41 & 53 \\
More than 20 min & 4 & 15 \\
Total & $100 \%$ & $100 \%$ \\
& $n=82$ & $n=72$
\end{tabular}

Distance willing to travel?

Pearson $\chi^{2}=5.185, P<0.075$, Cramer's

$$
\mathrm{V}=0.183
$$

Up to $2 \mathrm{mi}$

2 to $5 \mathrm{mi}$

More than $5 \mathrm{mi}$

Total

$\begin{array}{cc}40 & 24 \\ 32 & 36 \\ 28 & 40 \\ 100 \% & 100 \% \\ n=82 & n=72\end{array}$

Time would spend during visit?

Pearson $\chi^{2}=11.327, P<0.003$, Cramer's

$$
\mathrm{V}=0.272
$$

Up to $10 \mathrm{~min}$

10 to $30 \mathrm{~min}$

More than $30 \mathrm{~min}$

Total

\begin{tabular}{cc}
29 & 12 \\
54 & 49 \\
17 & 39 \\
$100 \%$ & $100 \%$ \\
$n=81$ & $n=72$ \\
\hline
\end{tabular}

\begin{tabular}{lcc}
\hline Frequency or how often return? & & \\
Pearson $\chi^{2}=17.664, P<0.000$, Cramer's & & \\
$\quad \mathrm{V}=0.354$ & 54 & 20 \\
Less than once a month & 33 & 51 \\
Once a week to once a month & 13 & 29 \\
Once a week or more & $100 \%$ & $100 \%$ \\
Total & $n=76$ & $n=65$ \\
\end{tabular}

Response frequencies expressed as percentages.

malls are not linear; responses to vegetated conditions exhibit a slight decline at the variables' highest response levels but generally remain at higher frequencies than for the more barren streetscape.

Why is the relationship of landscape and patronage behavior important? Multiple parameters affect the revenue potential of a site. For instance, visit frequency and duration, and customer travel range, have implications. Respondents claimed greater travel times for a mall that is landscaped, suggesting an expanded trade area radius that potentially includes thousands of people within dense urban population centers. Many businesses in strip malls are small, independent, startup enterprises. Increasing the amount of time spent by returning customers and having more people who have traveled greater distances to a mall site may translate to greater sales revenue (Underhill 1999) and perhaps a higher success rate for new entrepreneurs.

\section{Product Pricing}

The urban forest is a public good, rarely generating products that can be directly exchanged on markets. A pricing assessment was done using contingent valuation method (Mitchell and Carson 1989) to assess the impact of site landscape on local economics. Respondents were presented with a list of goods and services that
Table 3. Products pricing-scenario comparisons.

\begin{tabular}{llll}
\hline & \multicolumn{2}{c}{ Scenarios } & \\
\cline { 2 - 3 } & $\begin{array}{l}\text { No } \\
\text { Vegetation } \\
\text { Index }\end{array}$ & $\begin{array}{l}\text { Mature } \\
\text { Vegetation } \\
{[\text { Mean }(\mathrm{SD})]}\end{array}$ & $\begin{array}{l}\text { Independent samples } \\
\mathrm{t} \text {-test }\end{array}$ \\
\hline $\begin{array}{c}\text { Convenience } \\
\text { goods }\end{array}$ & $7.74(3.23)$ & $10.34(4.10)$ & $\begin{array}{c}\mathrm{t}=-3.840, P<0.000, \\
\mathrm{df}=116\end{array}$ \\
$\begin{array}{c}\text { Shopping } \\
\text { goods }\end{array}$ & $37.88(16.60)$ & $52.96(17.68)$ & $\begin{array}{c}\mathrm{t}=-4.650, P<0.000, \\
\mathrm{df}=110\end{array}$ \\
$\begin{array}{c}\text { Specialty } \\
\text { goods }\end{array}$ & $54.64(26.25)$ & $67.24(24.58)$ & $\begin{array}{c}\mathrm{t}=-2.220, P<0.03, \\
\mathrm{df}=79\end{array}$ \\
\hline
\end{tabular}

would be available in a strip mall, representing product classes generally used by marketers: convenience, shopping, and specialty goods.

Respondents were asked to state the price they would be willing to pay for each of 15 items. Three index variables were constructed. Significant differences were found when comparing means (Table 3). Respondents reported lower values for goods in the No Vegetation mall. Price differences between scenarios are considerable: approximately $34 \%$ for convenience, $40 \%$ for shopping, and $23 \%$ for specialty goods. Analysis using weighted standardized scores across all products generated a more conservative $8.8 \%$ difference, a finding consistent with the $9 \%$ to $12 \%$ range found for central business districts (Wolf 2005). An "amenity margin" in pricing represents potential revenues that can offset landscape investment and management costs.

\section{DISCUSSION}

This and prior studies indicate that public response to retail landscapes extends from what is visually pleasing to implications for shopper actions. A four-concept framework—visual quality, place perceptions, shopper patronage, and product pricing-guided a comprehensive measures approach that demonstrates the value of a green consumer environment. The product pricing results are often of greatest interest to merchant audiences, but other measures yield insights as to why shoppers may be willing to pay more for products in malls having better landscape quality.

Study images displayed a range of streetscape revisions. Public judgments of visual quality were most enhanced by the presence of trees and associated vegetation. Landscape influences obvious place qualities and provides cues of retail experiences for which there is no direct information. Although preference ratings were higher for landscaped settings, ratings of this study fell short of the highs in studies of central business districts (Wolf 2005), suggesting concerns about strip malls and reduced visual quality.

Positive judgments about maintenance and image were also associated with the presence of landscape, despite the scenario base images having the same levels of building care and site tidiness. Respondents also attributed social traits and characteristics of the in-store experience based on vegetation conditions. Judgments of products and merchants were more positive in heavily landscaped places as were inferences about product value, product quality, and merchant responsiveness.

Urban greening advocates are often challenged to demonstrate fiscal benefits from trees and other vegetation in urban settings. Responses on patronage variables relate directly to revenue potential, because they indicate a potentially expanded customer 
base for a business site. Also, respondents consistently reported greater willingness-to-pay values for goods and services in the landscaped mall at an overall rate of $8.8 \%$.

\section{Planning and Management}

The constructed scenarios presented extreme vegetation conditions. It should not be assumed that there is a linear relationship between various landscape treatments and retail behavior. Nonetheless, the results of this study have implications for vegetation planning and management in urban streets and corridors.

\section{Planting Spaces}

Based on public preferences, the space allocations for vegetation should be reconsidered. Municipal and county code may require perimeter landscape, but the widths of the planting zones are usually inadequate. Narrow planting strips that limit the quantity and quality of soil cause plant stress and force plant-to-infrastructure conflicts such as heaved paving. Better site design may be able to achieve identical functional requirements (e.g., building footprint and parking) yet provide larger consolidated spaces more suited to plants.

Many local governments are promoting or requiring low-impact development practices to improve stormwater management. Lowimpact development physical features (such as bioswales and rain gardens) can be designed and landscaped to serve multiple functions. Although they may be installed for water control purposes, their quality and character can also serve as a retail amenity.

\section{Visibility and Vegetation Configuration}

Reduced visibility of storefronts and signage resulting from vegetation is a major concern of merchants. The reduced ratings on wayfinding perceptions confirmed that customers are not as likely to see internal businesses if a mall is surrounded by trees. Two solutions are possible.

Large trees were associated with the highest visual ratings. Careful management and pruning for building views can enable greater street level visibility while sustaining the amenity values that big trees provide for shoppers. Merchants should understand the life cycle of trees in that young trees are short and sparse enabling storefront views followed by an interim period of growth that may limit visibility for several years. Later canopy raising and thinning of large trees by pruning is a better management strategy for visual quality enhancement than topping at sign levels or planting smaller trees whose mature canopy height is the same as business windows and signage.

Midrange visual responses offer a compromise in planting design. Larger, more upright vegetation can be planted intermittently to create a green "frame" to momentarily focus a driver's eye. Presenting businesses and their products using vegetation frames may help drivers to more easily distinguish individual retailers within an unceasing stream of complex roadside stimulus and reduce visual distractions that can influence driver response and safety.

\section{Signage Design}

Signage may be the ultimate point of tension concerning tall vegetation and business visibility. Individual businesses typically have large signs above their storefronts, ideally visible from the road, and may have individual signs closer to the road. These signs are often placed at considerable cost.

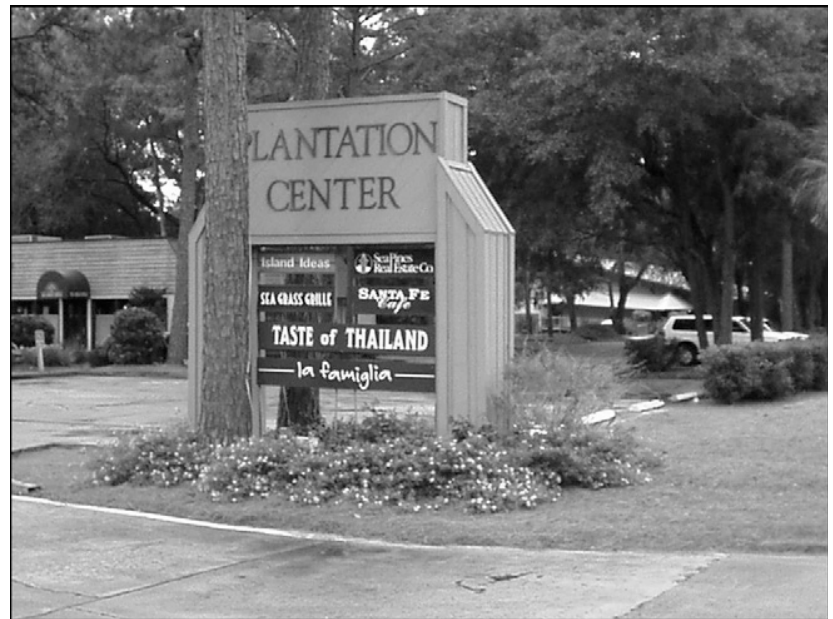

Figure 3. Streetside monument signage.

In many communities, there is an inherent conflict between perimeter or property-edge plantings, as required by commercial zoning code, and sign requirements on buildings. If a small mall owner complies with both sets of requirements, sight lines are soon conflicted. Local requirements may inherently lead to customers not being able to identify businesses and products. Code revisions are needed.

One solution is to move signage to the front of or in the midst of landscape vegetation. Monument signs are an example (Figure 3). This signage style enables a business community to conserve a full landscape complement of trees, understory shrubs, and groundcover. Second, it reduces visual distraction because drivers come to expect foreground visual targets that quickly convey the entire complement of merchants, goods, and services that they will find within a mini-mall. Colorful low-growing vegetation at the base of the sign can further direct a driver's attention to the business listing.

\section{CONCLUSIONS}

The limited geographic application of this study and a low survey response rate may limit generalizability of the findings. Yet positive public response to city trees in the retail environment is consistent with multiple recent studies. Additional research would confirm the perceptual and behavioral relationships of nature and commerce. Trees and retail environment studies should be replicated in urban areas of other biogeographic zones, across various retail settings, across seasons, and target a broader array of human demographic groups. In situ data recording of pricing and behavior across retail vegetation conditions would address issues of survey self-reporting and nonresponse biases.

This study investigated consumer response in a prevalent retail setting. Small malls are ubiquitous in cities of many industrialized nations, are frequented by many shoppers, but may be held in disdain by some. They are the places where many small business dreams begin, then grow or fail. Communities are ever more interested in creating transportation corridors that support entrepreneurship but provide a better experience of place and environmental services. Results of this study indicate that the presence of trees and smaller plants positively influences public response to strip mall settings. Roadside landscape and 
vegetation contributes to the environmental quality of the urban environment and retail vitality.

Acknowledgments. Research was supported by the International Society of Arboriculture (Duling Grant) and Horticultural Research Institute. Manuscript preparation was supported by Awaji Landscape Planning and Horticulture Academy, University of Hyogo, Kobe, Japan. Additional information can be found at: www.cfr.washington.edu/ research.envmind.

\section{LITERATURE CITED}

Dwyer, J.F., H.W. Schroeder, and P.H. Gobster. 1994. The deep significance of urban trees and forests. In: Platt, R.H., R.A. Rowntree, and P.C. Muick (Eds.). The Ecological City: Preserving \& Restoring Urban Biodiversity. University of Massachusetts Press, Amherst, MA.

Elmendorf, W.F., and A.E. Luloff. 2001. Using qualitative data collection methods when planning for community forests. Journal of Arboriculture 27:139-151.

Evans, G.W., and K.W. Wood. 1980. Assessment of environmental aesthetics in scenic highway corridors. Environment and Behavior 12:255-273.

Florida, R. 2005. Cities and the Creative Class. Routledge, New York, NY. 198 pp.

Herzog, T.R., and T.A. Gale. 1996. Preference for urban buildings as a function of age and nature context. Environment and Behavior 28:44-72.

Kaplan, R., and S. Kaplan. 1989. The Experience of Nature: A Psychological Perspective. Cambridge University Press, Cambridge, MA. 340 pp.

Laverne, R.J., and K. Winson-Geideman. 2003. The influence of trees and landscaping on rental rates at office buildings. Journal of Arboriculture 29:281-290.

Lohr, V.I., C.H. Pearson-Mims, J. Tarnai, and D.A. Dillman. 2004. How urban residents rate and rank the benefits and problems associated with trees in cities. Journal of Arboriculture 30:28-36.

Mitchell, R.C., and R.T. Carson. 1989. Using Surveys to Value Public Goods: The Contingent Valuation Method. Resources for the Future, Washington, DC. 463 pp.

Nasar, J.L. 1987. Environmental correlates of evaluative appraisals of central business scenes. Landscape and Urban Planning 14:117-130.

Nassauer, J.I., and D. Larson. 2004. Aesthetic initiative measurement system: A means to achieve context-sensitive design. Transportation Research Record: Journal of the Transportation Research Board 1890:88-96.

Sheets, V.L., and C.D. Manzer. 1991. Affect, cognition, and urban vegetation: Some effects of adding trees along city streets. Environment and Behavior 23:285-304.

Smardon, R.C. 1988. Perception and aesthetics of the urban environment: Review of the role of vegetation. Landscape and Urban Planning 15:85-106.

Sommer, R., H. Guenther, and P.A. Barker. 1990. Surveying householder response to street trees. Landscape Journal 9:2:79-85.

Stewart, M. 2005. Strip malls shine in retailing firmament. Business Edge 2, 26. www.businessedge.ca/article.cfm/newsID/11471.cfm (accessed 10 July 2007).

Strip Mall. www.en.wikipedia.org/wiki/Strip_mall (accessed 31 July 2007).

Ulrich, R.S. 1986. Human responses to vegetation and landscapes. Landscape and Urban Planning 13:29-44.

Underhill, P. 1999. Why We Buy: The Science of Shopping. Simon and Schuster, New York, NY. 255 pp.

Wolf, K.L. 2003. Freeway roadside management: The urban forest beyond the white line. Journal of Arboriculture 29:127-136.

2004. Nature in the retail environment: Comparing consumer and business response to urban forest conditions. Landscape Journal 23:40-51.
2005. Business district streetscapes, trees and consumer response. Journal of Forestry 103:396-400.

- 2006. Assessing public response to the freeway roadside: Urban forestry and context sensitive solutions. Transportation Research Record: Journal of the Transportation Research Board 1984:102-111.

2007. City trees and property values. Arborist News 16:34-36.

\author{
Kathleen L. Wolf \\ Research Social Scientist \\ College of Forest Resources \\ University of Washington \\ Box 352100 \\ Seattle, WA 98195, U.S. \\ kwolf@u.washington.edu
}

Résumé. Les allées commerciales sont communes en milieu urbain, historiquement favorisées par les pratiques de zonage aux États-Unis qui consistent à concentrer le commerce de détail dans une étroite bande le long des grandes artères. Plus récemment, les communautés ont redéveloppé les allées commerciales en augmentant les aménagements paysagers afin de créer un milieu plus convivial. Cette étude vise à évaluer la réponse du public face à diverses options de paysages et de forêts urbaines. L'enquête a permis de décrire une variété d'allées le long des voies publiques et d'aménagements le long de ces dernières. Les résidants de trois villes majeures de la Côte Nord-ouest du Pacifique des États-Unis ont été questionnés sur leurs préférences et leurs perceptions concernant un concept autour de quatre éléments de base: la qualité visuelle, les perceptions face au commerce de détail, le comportement de la clientèle, les prix pour les biens et les services. Les répondants préféraient des allées paysagères et ont indiqué être prêts à payer jusqu'à $8,8 \%$ de plus pour les biens et services dans des allées commerciales bien aménagées. Des lignes directrices de gestion des allées commerciales sont proposés à partir des résultats de cette recherche.

Zusammenfassung. Streifenförmige Einkaufszentren sind eine übliche Form der Landnutzung, die historisch hervorgegangen sind aus der amerikanischen Praxis, Großhandel und kommerzielle Entwicklung entlang von Hauptverkehrsadern anzusiedeln. Seit kurzen werden diese Streifen-Einkaufszentren neu entwickelt und Landschaftsflächen ausgeweitet mit dem Ansatz, ein Gefühl für den Platz zu entwickeln. Diese Studie bewertet die öffentliche Reaktion auf urbane Forstflächen und Landschaftsoptionen. Umfragen beschrieben zahlreiche straßenbegleitende, grundstücksbegrenzende Maßnahmen. Die Anwohner dreier Hauptstädte im pazifischen Nordwesten der USA wurden befragt, ihre Vorlieben und Vorstellungen bezüglich eines 4-Punkte-Rahmenkonzepts: ästhetische Qualitäten, Großhandelsvorstellungen, Eigentümerverhalten, und Preisgebung für Waren und Dienstleitung darzulegen. In den Antworten wurden landschaftsgestaltete Seitenstreifen bevorzugt und positives Großhandelsverhalten berichtet sowie die Bereitschaft 8,8\% mehr für Waren und Dienstleistungen in landschaftlich gestalteten Räumen auszugeben. Basierend auf diesen Forschungsergebnissen wurden Richtlinien für die Gestaltung von straßenbegleitenden Grundstücken gegeben.

Resumen. Los mini-malls son un uso común de los terrenos urbanos, históricamente promovido en los Estados Unidos en zonas que concentran desarrollo comercial al por menor en una banda estrecha a lo largo de calles arteriales y principales. 
Más recientemente, las comunidades están rediseñando las zonas con mini-malls, expandiendo plantaciones en el paisaje como biotecnología, e intentando crear un sentido de lugar. Este estudio evaluó la respuesta pública al bosque urbano y diferentes opciones paisajísticas. Los formularios descritos variaron los tratamientos del lado de la calle y la propiedad. Los residentes de tres ciudades principales en el Noroeste del Pacífico, U.S. fueron cuestionados para indicar sus preferencias y percepciones concernientes a una estructura de cuatro conceptos: cualidad visual, percepciones de venta al detal, patrón de comportamiento y precios de bienes y servicios. Los cuestionados prefirieron los lados de las calles con paisajes y reportaron un comportamiento positivo tal como buena disposición a pagar $8.8 \%$ más por bienes y servicios en malls paisajísticos. El manejo de guías para las calles es propuesto con base en los resultados de la investigación. 